$\S=-1$ 圆

\title{
The Use of Violence in Indonesian Police Investigation
}

\author{
Hamidah Abdurrachman $^{1}$, Fajar Ari Sudewo ${ }^{2}$ \\ ${ }^{1,2}$ UniversitasPancasaktiTegal \\ *Corresponding author E-mail:hamidah.azzahara@gmail.com
}

\begin{abstract}
The tricky part of the investigation process in Indonesian Criminal Justice System is to balance the requirement to successfully uncover cases reported by the public while at the same time avoiding a violation of Human Rights at all cost. To do their duty, the police as investigators are given the authority to take measures such as arrest, detention, search, seizure and examination of letters. In implementing these forceful measures, the tendency of abuse to occur is highly likely, including but not limited on the use of violence to intimidate, evidence engineering, false arrests, maladministration, and other forms of human rights violation. Some of the stages within the investigation process that often use violence as a means to an end are during arresting, interrogating, investigating, and giving detention to suspects. The form of violence in use includes physical and psychological ones, with one of the most extreme examples involving the use of automatic weapon to inflict pain.

This study is a result of an empirical research into the use of violence in Indonesian police investigation. We use primary and secondary data sources, including laws, literature, and doctrine, before analyzing the data qualitatively. This research is expected to contribute in further strengthening the principle of Due Process of Law in the implementation of the police investigation process. Even though the principle of Due Process of Law is well known in the Law on Criminal Proceedings of Indonesia, its application is still considered as weak. It is the contention of this paper that the principle of Due Process of Law should be included in the Police Chief Regulation and the regulations within the Code of Police.
\end{abstract}

Keywords: Violence; Police Investigation; Human Rights

\section{Introduction}

Investigation is what investigators do to collect existing evidences and find the suspect in uncovering a case. According to the Indonesian Police organizational structure, this investigation function lies within the responsibility of a special unit called Reserse Kriminal or Crime Investigation unit. There is a set of negative perception surrounding this Crime Investigation unit as explained below (1):

Firstly, from a moral perspective, some of Indonesian Police Officer (INP) investigators are deemed corruptible andeasy to bribe. They are frequently misusing their power for extorting and occasionally conspiring with legal case suspects. INP investigators are also viewed as discriminative, especially in the process of investigating legal cases.

Secondly, in regard to their intellectual capacity, some INP investigators are deemed lacking in solid understanding about the law regulations concerning crimes. Including but not limited to knowledge needed to deal with various trans-national crimes (Drugs, Terrorism, Cyber Crime) and crimes against state properties (Illegal logging, Illegal Fishing, Illegal Mining).They are also lacking in organizational skill, especially in regard to organizing crime scene reconstructions and uncovering cases in Forensic Laboratory.

Thirdly, regarding their expertise and competencies, some INP investigators are deemed unresponsive in following-up people's complaints and unskilful in searching and arresting those involved in legal cases. They are often committing human rights violation in the process of arresting, detaining, and examining witnesses and suspects. They also often fail to comply with administrative procedures (not bringing along arrest warrant) in performing the arrest.

Until today, the use of violence in police duty implementation remains. Despite the many ways that have been done to cease it, the use of violence in the investigation processes has been an accepted method for police to do their job.

As what KontraS (Komisiuntuk Orang Hilangdan Korban Kekerasan/Commission for Missing Persons and Victims of Violence) has noted ("KontrasRilisPraktekPenyiksaan 2014-2015", 2015), in 2014-2015 there are 554 series of violence and human rights violation committed by INP officers. The most dominant ones are the use of unjustified shooting (272 events), torture (84 cases), and causing deaths (299).

Indonesian National Police Commission's report (2015) illustrates the police function performance. Out of 1270 complaints from society to Kompolnas in 2015 , the Crime Investigation function has been the most complained problem with 1187 complaints (93\%), 3 complaints (0.2\%) toward Samapta (Rapid Response Unit), 11 complaints $(0.8 \%)$ toward traffic unit, and the remaining functions amounting to 51complaints $(5.3 \%)$. The Crime Investigation is the police's function in providing services in law enforcement which has high possibility of being violated. Such violation takes form in poor service provision, authority misuse, incorrect discretion, discrimination, and suspected corruption perpetrated by the INP members of Crime Investigation function.

One of the cases that received a social scrutiny is the attempt of Densus 88 (Special Detachment 88 ) to arrest Siyono in his house in Klaten Regency, Central Java, in March 8, 2016. Police claimed that on their way to bring the suspect to the police station, a fight broke out between the Police and the suspect, resulted in the sus- 
pect fainting from fatigue and then died. However, according to The National Commission of Human Rights ("KematianSriyonoLayakDisebutSebagaiPelanggaran HAM", 2016), the primary cause of Sriyono's death is bone fracture in his chest that affected his heart tissue.

We can see similar cases also happened as descripted below:

a. In 2014, Kuswanto was arrested by the officers from Kudus Precinct Police (Polres) with the allegation of being involved in a robbery of a "Walls" Ice Cream Shop ("KisahKuswanto, Korban Salah Tangkap yang Dibakar”, 2014). Kuswanto was forced to admit the allegation made by the police. Since he did not commit it, Kuswanto denied the allegation and he was deemed as uncooperative.Blind folded and handcuffed, Kuswanto was poured with gasoline and burnt with a matchstick. One year after the incident, Kuswanto knew that the police had successfully arrested the real culprit from the mass media. Hence, Kuswantowent to make a report to Organization for Witness and Victim Protection (LPSK) requesting the burns he had suffered from the fatal error of police members to be treated properly.

b. In 2014, a child was arrested by the Crime Investigation Unit of Tingkir Sub-Precinct Police (2). Caesar Alif Arya Pradana (15), a student of IX-G Class from SMP 4 Salatiga experienced a serious trauma after he was brutally arrested. Caesar was handcuffed, while his mouth and eyes were duct-taped af ter two police members rummaged his bag. Caesar was arrested when he was about to get into his class. He was suspected to get involve in a motorcycle theft case. The two police members forced Caesar to admit the accusation by interrogating him inside a car which was driven around the city.

c. In 2014, Zulfikar and Bahruddinwere arrested by sixmembers of Metro Central Jakarta precinct police for the alleged case of robbery to a house in SawahBesar on March 27, 2014 (2). While their friend, Zulkifli, who was also arrested along with them, was released the next day, Zulfikar and Bahruddin are detained in Salemba penal institution. During examination, Zulfikar and Bahruddin received physical and psychological violence. The police forced them to admit the allegation. It was later discovered that during the arrest, the sixpolice members did not have any arrest warrant with them. A witness also saw how Zulfikar was hit, choked, and stepped on repeatedly and forced to admit the allegation during the arrest. Zulfikar's money amounting to Rp. 10,000,000.-(\$800) was also taken by the police. Later on, it was found out that Zulfikar and Bahruddin were victims of false arrest.

d. In 2013, another case of false arrest resulting in victim persecution was also experienced by Rudi Hartono in Pamekasan, East Java ("Korban Salah TangkapPolresPamekasanSulitMakanTiga Hari", 2013).Rudi was pummelled by a police member (A.W). At that time, A.W said that he did it based on a match of physical characteristics and the identity of fraud and embezzlement culprit as reported bySuparto. However, when Rudi was confronted with Suparto, Suparto said that the fraud and embezzlement culprit under the report he made was not referring to Rudi.

e. In 2013, a police member, Bripka AH, who was tasked in Poso police precinct sexually harassed a female detainee, FM (24) (3). FM was a housewife who was arrested by the Drugs Unit of Poso Precinct Police when she was consuming crystal meth. $F M$ was raped twice at gunpoint.

\section{Literature Review (Heading 1)}

\subsection{The Police as Criminal Law Enforcer}

In (criminal) law enforcement, the national police are an institution with highly determinant position in the process of criminal case settlement. This is seen in the criminal adjudicative process system, where the police are the first institution to deal with a criminal case. The authority given to this institution gives birth to selection or filtering of law violation. This filtering means that the police will identify whether those unlawful actions are actually crimes or not. Police, then, has the following main duties: receiving a report or case from the public in case of a crime; performing preliminary and full investigation of a crime; filtering the cases which meet the requirements to be filed to a public prosecutor's office; reporting the results of an investigation to a public prosecutor's office; and ensuring that the parties involved in a criminal adjudicative process are protected. The public prosecutor's office in the next phase makes an indictment or charge to be delivered before a Panel of Judges of a Court who eventually decides the case.

In the criminal adjudicative process system, the police are the spearhead in law enforcement. However, police steps and movements are limited by a set of criminal law regulations, which in principles prohibit violence from being used in dealing with a crime suspect. In addition, there are also provisions regarding the police duties and authorities in handling a criminal case to save the police/officer themselves from overacting, and also to serve as instruments to guide them in performing their jobs.

Police duty and authority in criminal law enforcement is juridicially determined in Law Number 8 of 1981 concerning Criminal Law Procedures Codes (KUHAP) and Law Number 2 of 2002 concerning National Police of the Republic of Indonesia. The duties of Police of the Republic of Indonesia are divided into 2 (two), namely main duties and duties of policemen in duty. As stipulated in the Article 13 of Law Number 2 of 2002, the main duties of the Indonesian Police are:

a. Maintaining public security and order

b. Providing protection, shelter and care to the society

c. Enforcing the law

On the other hand, a criminal adjudicative process s ystem aims at deciding whether someone is guilty or not. A criminal adjudicative process is organized through a procedure as bound by strict regulations concerning verification of prove which cover all constitutional limitations and end in an examination process in a court. To realize this aim of criminal adjudicative process, Packer have presented two criminal adjudicative process models, namely due process model and crime control model (1968, p. 197).

The values underlying crime control model are (a) repressive action against a crime is the most important function of a adjudicative process; (b)the main attention should be paid to efficiency of a law enforcement to select suspect(s), determine their wrongdoing(ting such law enforcement process is the administrative model and one similar to managerial model; (d) the law enforcement process should give emphasis on the quality of administrative fact findings, since those findings will bring towards the release of a suspect from prosecution, or the suspect's willingness to declare themselves guilty or plead for guilty.

The values underlying the due process model are: (a) the possibility of "negligence of human nature "factor. This model prioritizes formal adjudicative and adversary fact-finding. It means every suspect's case should be filed before an impartial court and examined after the suspect obtains his/her full rights to deliver his/her defence; (b) emphasis on preventive measures and elimination to the farthest possible extent of any administrative mechanism error of an adjudicative process; (c)intact and primary placement of individuals in an adjudicative process and the concept of formal authority limitation, with considerable consideration of the combination of stigma and loss of independency which is deemed to be a revocation of one's human rights which can only be done by the state.

Due process model is based on "obstacle course", hence any officer in performing their duties shall be based on the predetermined rules of the game. In due process model, new values arise, namely the concept of protection of human rights and limitation of power in criminal adjudicative process. Thus, in this model, a criminal proceeding should be controllable in order to prevent any power abuse and authoritarian tendency for the sake of maximum 
efficiency. In this model, the so-called "presumption of innocence" is applied.

\subsection{The Form of Violence}

In his study on torture committed by law enforcers, Matthew Lippman (4) explains several techniques of persecution which include physical, psychological and pharmacological persecutions in the following forms.

Forms of physical persecution: (stick, wood).

Beating by hands/ kicking by feet or other tools

b.

Submarine technique: head is submerged continuously in dirty water tub/ in the toilet/ kerosene, while sexual organs are kneaded.

c. Electric shock to sensitive parts of body

d. Body extension: victim is crucified, beaten, electrocuted, or tortured sexually.

e. Water pipe technique: victim is tied and locked, blindfolded, nose is corked, a pipe is inserted to the mouth with a strong flow of water, making the victim distend and losing consciousness.

f. Phalange technique: suspect is locked to a chair and detainee's feet palms are hit with a key or pipe and forced to run until he/she is fainted.

g. Rubbing detergent or pepper to the eyes.

h. Extraction: removing teeth, nail, and pubic hair

i. Sexual persecution to women, rape using tools such as bottle/wood and to men, his genital is beaten, electrocuted, or his scrotum is tied with a rope and the other end of the rope is tied to a car jack which is then dropped.

j. Rolling: suspect/detainee is tightly tied to a bed with a wet bedsheet. The bedsheet is then squeezed until it dries to let it choke him and it is repeated several times. Forms of psychological persecution, including:

a. Sensory removal: head is covered or placed/locked in a dull environment with no sensory stimuli.

b. Death threat, rape to themselves, their family, or forced to watch an execution of their friend.

c. Drug: injected with certain harmless liquid, while the torturer pretends that it is a poison.

d. Forced to stay bare-naked in a cold and wet cell, often full of insects, or admitted into a cell with mentally ill patients.

e. Forms of pharmacological persecution:

f. Use of drugs that make him/her gloomy or depressed, or other drugs leading to paralysis.

g. Use of alcohol to make him drunk, before being asked to admit allegations.

The most standard technique during interrogation process is intimidation, while being beaten/kicked using either parts of body or tools such as stick, wood, bottle and others. Victims are forced to admit all accusations. When the response is not what the interrogators want, violence occurs.

\section{Methodology/Materials}

Legal research is a process of finding legal regulations, legal principles, and legal doctrines in order to answer issues at hand (5) This research is a juridical normative study, i.e. the research on positive legal rules and legal principles which was conducted by evaluating the relevant legal rules (regulations of law). This research of evaluating positive law is conducted by evaluating the consistency of one legal rule with another legal rule, or with a legal principle which is acknowledged in the existing legal practices. It is also done by reviewing literature or secondary data Normative legal research is a scientific research procedure to discover the truth based on legal discipline logic from its normative side.
This research uses several approaches, namely Statute Approach, which is performed by reviewing the laws regarding violence in interrogation and Case Approach where case review is made toward violence cases committed by policemen to crime suspects. We use theories and legal principles with qualitative approach to analyse the cases in order to comprehend the causal factors.

\section{Results and Findings}

According to Adji, police behaviours which are frequently criticized are those which involve the use of violence in performing their duties (1998), "such behaviours have become a culture, particularly in an investigation to get the suspect admitting the accusation" (p. 4). This is proven by the results of many studies over the years, just as indicated by Purwanti's research (6) in Central Java where INP investigators are found to have not reached the expected professionalism. Abdurrachman (7)also proves that violence can still be found during investigation process by the police in Tegal. While in Bandung, Susanto finds a similar occurrence. Raharjo and Angkasa's research (8) also points toward the existing violent pattern during investigation processes by the police in Jakarta and Banyumas. This provest hat there is violence involved in the investigation process made by investigator towards the suspect.

However, historical and cultural factor is not the sole determiner of the police's violent behaviour. The police as law enforcer is always demanded to complete the case they handle, the results of which are then reported to the public as a form of their accountability to the society. In other words, the police are always under pressure to perform their job well and without failure, and these pressures come from many directions. Inevitably, these pressures drive the police to frequently lose their control, patience, and prudence in examining suspects (9) In order to understand the causal factors of violence, Weber's theory suggests that the visible human behaviour is a consequence of a number of views or doctrines living in the doer's head. Thus, there are a number of definitions, limitations, or complexity of meanings living inside the doer's head, resulting in the explicitly expressed behavioural subjective interpretive reality (10).

To explain human behaviour through analysis of meaning, a theory of Symbolic Interactionist proposed by Charles Hartonand W.I. Thomas can be useful in explaining how human behaviour relies on three premises (10).

Firstly, that human do towards something based on the meaning inherent to that something. It means that in that something there is a meaning, that this something is just a symbol of a meaning, and human behaviour is show to chase that meaning itself (people do not act towards things, but toward their meanings).

Secondly, that the meaning about this something develops from or through interaction between humans in their daily lives, in line with the current flow of cultural development itself as a result of "shared system of meaning". The said meanings are learned, revised, maintained and given limitations in human interaction context.

Thirdly, these meanings are held, referred to and interpreted by someone in interacting with something he/she is facing. They are used as a reference to interpret a situation, condition, object, or others in their daily life.

This perception theory can be seen in the police job against these principles (7):

\section{a) Presumption of Innocence Principle}

Presumption of Innocence Principles governed in Indonesian Law No. 48of 2009concerning Judicial Power, Article 6 Paragraph (2) which formulates as follows: "no one could be penalized, unless when the court, for the valid exhibits under the law, obtain a belief that someone who is deemed to be responsible has been found guilty for the action alleged to him". This principle is also found 
in the explanation of KUHAP: "Anyone who is suspected, arrested, detained, charged and or brought before a trial of court, must be deemed innocent until an order from the court stating his guilt is issued and such order has obtained a permanent legal force".

The elements in Presumption of Innocence Principle are the main principles of citizen's right protection through a fair and trustworthy legal proceeding, including protection from arbitrary measures from the state officials, since it is the court which is entitled to determine his guilt and the trial of court should be open in nature and shall never be a secret (Reksodiputro, 1994, p. 36). Suspect/defendant should be given a guarantee that he/she will be able to fully defend himself/herself". This is what is called as "accusatory principle", which places the suspect as a subject, rather than an object. Someone who is in the position of a suspect should be guaranteed for his rights in a proportional manner.

Presumption of innocence principle is the one closest to police duties for they are in the frontline of criminal law enforcement. Since the onset, the police work based on suspicions, i.e. when a crime comes to their knowledge, then they should do some efforts by collecting evidences, in order to make the crime clear and to find the suspect. If sufficient evidences about the crime and the suspect have been found, then, investigator has obtained a presumption of guilty suspect ("presumption of guilt"). According to Susanto (11), this presumption of guilt towards the suspect usually brings about a consequence for the investigator to perform forceful measures such as arrest and detention for an efficient investigation process.

The manifestation of this presumption of innocence principle is seen in humane treatment as well "as fulfilment of suspect's rights in accordance with the applicable regulations. According to Erdiansyah (12), there should be no intimidation, coercion, terror, or even fatal physical torture which may lead to the suspect's death Based on the Presumption of Innocence Principle and equality in law principle, the objectives of this principle should be fulfilled, because it is obvious that every suspect must obtain all of his rights with no exception. As someone who has not been found guilty, he should obtain his rights such as the right for immediate examination during the investigation process, the right for immediate court examination and for the fairest possible order, the right to be informed of what he is accused of/charged with, the right to prepare his defence, the right to obtain legal assistance, the right to be visited by his family, as well as other rights in accordance with the objectives of KUHAP included in Law No.8 of 1981.This is consistent with the Due Process of Law Principle in the criminal law procedure enforcement in Indonesia. The Due Process of Law principle constitutes the objective of KUHAP itself, that is to support the creation of a fair adjudicative process.

\section{b) Legal Assistance Principle}

Article 54 of KUHAP suggests: for the purpose of defence, the suspect defendant has the right to obtain legal assistance from one or more lawyers, during and the period and in every level of examination. Even in Article 56 of KUHAP,the existence of a lawyer is required in case the suspect is charged with a crime punishable by death penalty, or fifteen-year imprisonment sentence, or in case the suspect's alleged crime is threatened with an imprisonment for five years or more.

In the Indonesian Criminal Law Procedures Codes,Article 114, it is also said that prior to examination by investigators, suspect must be informed of his rights to obtain legal assistance or he must be accompanied by lawyers. In any case, the suspect must be accompanied by lawyers. As mentioned above, this has been consistent with the "fair trial" and "constant justice" principles, with consideration that the suspect in such case could be detained However, in its implementation, the duties of this lawyerare limited by the Indonesian Criminal Law Procedures Codes Article 115 , i.e. in preliminary examination he is limited to such extent of seeing and listening how the examination goes. Even in a case of crime related to the state security, the lawyer could only watch. Hence, as stated by Prodjohamidjojo (13), it is safe to say that the role that a lawyer play in this preliminary examination is passive. In reality, when someone begins to get involved in a legal conflict with the police, they do not even know and are not informed of their rights; even their family are not allowed to be contacted, let alone talking about lawyer. Even in some cases, the family do not have any idea where their member who is "taken" by the police is and they should find out the information themselves. The results of research find that the police perceive that this right to have legal assistance is not binding. Thus, this makes this implementation of suspect's rights in obtaining legal assistance limited, while in reality this right is the most fundamental human rights.

As an organization, the police are a bureaucracy administered by human as the actor, meaning that the police work to serve the society and it is implemented by humans who are bound to the detail of applicable duties, authorities, and regulations. In addition, as a professional organization, the police is demanded to show professional attitude and bureaucratic character. It is said so since this organization is the kind of organization designed to deal with administrative tasks at great scale and to coordinate the works of many people in a systematic and rational fashion (14).

One of the objectives this organization has always been targeting is to respond to a crime by making an inventory of the crime itself. According to Susanto (11), the success of this organization is when the Clearance rate or Crime Clearance is achieved. To pursue this target, the police as an organization is prepared rationally, taking the actions which are based on consideration of and interest in reaching the objective rationally and economically, involving, trying to obtain anything the organization itself could benefit from as much as possible; trying to suppress up to the minimum limits any load that causes pressure to their organization.

Thereby, the effort of fulfilling the "Clearance rate" target has dominant influence on the police's (investigator's) behaviour in order to perform their investigation duties. It is understood since the Clearance rate target is the objective closest to the police institutional objective in a criminal adjudicative process system, i.e. settling criminal cases or crimes in the most possible efficient way, even if it means to sometimes deviate from or manipulate the proper legal procedure.

The use of violence by the police around the globe is a big problem, particularly in those countries following democracy. However, it is worth-noting that there is a perception regarding this use of violence between the society and the police. The society believe that the use of violence is something exceptional, and it should never be a norm. The police have limited the use of physical power/weapon only under emergency, i.e. there is a threat to the society or to a police member. When violence is overused, then, violence has become a part of their job. In other words, violence has become functional to police work implementation.

In its practice, violence is used to obtain confession. In Idonesian Criminal Law Procedures Codes, Article 184, no exhibit called "confession" is stated, but this "confession" is included by the Police as an indicative exhibit. Investigators say it is done to prevent the Project Inspection Minutes from being rejected by the Public Prosecutor's Office. Confession in an investigation is actually a heritage of Civil Procedure Law (Her Indische Regulatie), Article 295 item 3e,which put confession as a valid exhibit. However, upon the applicability of Indonesian LawNumber 8 of 1981 concerning Criminal Law Procedures, confession is not an exhibit, yet it can still be used. The problem that causes the occurrence of violence lies with the difficult verification process since when the crime occurs no report is immediately made. In Angho and Sun An'scase in Medan ("Kasus Sun Ang - AngHo", 2012),despite the report about the violence made by the conflict, no evidence was available to escalate the violence as a crime in investigation. There were neither witnesses nor (physical examination) report.

Referring back to the Anti-Torture Convention (Convention against torture and other cruel inhuman or degrading treatment or punishment),particularly Section I Article 4, it is stated that all tortures are offense in accordance with criminal law and the obligation to sanction it lies with the state so that the state could take 
the necessary steps to apply such sanction (Nusantara, 1995).The provision in Law No. 2 of 2002concerning the National Police of the Republic of Indonesia, Article 19 paragraph (1) asserts:"In performing their duties and exercising their authorities, officials of the National Police of the Republic of Indonesia should always take measures based on legal norms and in consideration of those norms of religion, decency and moraly as well as upholding human rights". Technically, in the Regulation of National Police Chief No 14 of 2011 on Police Professional Code of Ethics (15), it is determined in article 14 that every investigator is prohibited from exercising any coercion to obtain confession when they are examining someone. However, this provision stated no sanction for its violation. The same also goes to the right to obtain legal assistance as governed in article 54 of Regulation of National Police Chief No 14 of 2011 on Investigation Management.

So far, the society hold a perception that the police and their investigators have always been too textual in enforcing the law. Firstly, investigators often use positivistic approach when they apply the law to a case. What the law states have been mandatory for the police to implement with no exception. Secondly, the law enforcement has always been less democratic. The police are a law enforcer who frequently faces the society. Despite living together with the society, the police often fail to absorb the justice values living in their society and to understand what the society need. In several cases, the investigators enforce the law merely for legal purpose, rather than the society's interest. Investigators make the law as the final objective of law enforcement, that is to punish the suspect (1616). This is quite contradictory, considering that law is fundamentally an instrument, not an objective.

\section{Conclusion}

1. Due Process of Law principle is the proper or fair legal process which constitutes the principle of Criminal Law Procedure in Indonesia which should be enforced during preliminary or full investigation process. This principle should be developed further and should serve as a guideline to pay more attention to and protect human rights.

2. The key to violence incident to occur lies with the investigators themselves. Even though they have attended a number of trainings held both domestically or abroad to support their expertise, when they return to perform their duties in crime investigation unit, they resort to the old ways of doing their job. This is influenced by the perception towards the suspect which is deviating from the presumption of innocence principle.

3. In the future, the investigation model should be executed using scientific investigation approach, where the police processes all exhibits scientifically, and find the culprit later. This scientific investigation model would evade any form of intimidation, threat, and physical and psychological violence. The use of this scientific investigation approach goes hand in hand with the progressive legal approach in investigation to deal with stagnancy in the less scientific investigation methods.

4. Improving the role that lawyer plays in accompanying a suspect is one of the solutions to prevent any violence from occurring.

5. Close monitoring from the Investigator's immediate supervisor to control how the investigation is being held is of high importance. This can be supported by installing a surveillance tool such as closed-circuit television (CCTV)for monitoring purpose. When a right violation occurs, the Police Professional Code of Ethics has established a mechanism and an institution assigned to perform the corrective measures, yet its implementation is highly influenced by to what extent the ability and courage of their supervisors to take firm measure against any member committing violence. As agreed 1 ), The main important things are to follow up any violation cases found during investigation processes and measure the effectiveness of the monitoring process and to follow up any violation cases found during investigation processes.

\section{References}

[1] Agussubagyo1978. MEWUJUDKAN PENYIDIK POLRI YANG PROFESIONAL DAN BERMORAL. 2015

[2] Hidayat MA. Pelajar SMP Digebuki Oknum Polisi Dipaksa Mengaku Maling Motor. 2014

[3] Fadillah R. Sebelum memperkosa, Bripka Ah pesta narkoba di ruang tahanan. 2013.

[4] Lubis TM. Hak-Hak Asasi Manusia Dalam Masyarakat Dunia: Isu dan Tindakan. Yayasan Obor Indonesia, Jakarta. 1993

[5] Marzuki M. Penelitian Hukum: Edisi Revisi: Prenada Media; 2017.

[6] Purwanti A. Profesionalisme Polisi di Bidang Penyidikan: Tesis. Semarang: Program Magister Ilmu Hukum Undip; 1996.

[7] Abdurrahman H. Upaya Perlindungan Hak Asasi Manusia Terhadap Tindakan Kekerasan Oleh Polisi dalam Penyidikan di Wilayah Tegal: Tesis. Semarang: PPS Ilmu Hukum UNDIP; 2000.

[8] Raharjo A, Angkasa A. PROFESIONALISME POLISI DALAM PENEGAKAN HUKUM. Jurnal Dinamika Hukum. 2011;11(3).

[9] Raharjo A, Angkasa A, Nugroho H. RULE BREAKING DALAM PENYIDIKAN UNTUK MENGHINDARI KEKERASAN YANG DILAKUKAN OLEH PENYIDIK. Jurnal Dinamika Hukum. 2013;13(1).

[10] Faisal S. Penelitian kualitatif: dasar-dasar dan aplikasi: YA3; 1990.

[11] Susanto I. Kajian Sosiologi Terhadap Polisi. Simposium Nasional Polisi Indonesia, Semarang. 1993

[12] Riau JIH. Kekerasan dalam Penyidikan dalam Perspektif Hukum dan Keadilan. Jurnal Ilmu Hukum Riau.1(01).

[13] Prodjohamidjojo M. Pembahasan hukum acara pidana dalam teori dan praktek: Pradnya Paramita; 1989.

[14] Beetham D. Birokrasi. Bumi Aksasara, Jakarta. 1990.

[15] Kapolri P. Peraturan Kapolri Nomor 14 tahun 2011 tentang Kode Etik Profesi Kepolisian Negara Republik Indonesia. 2011.

[16] Wicaksono DA. REVITALISASI SUMBER DAYA MANUSIA POLRI UNTUK SINERGITAS KINERJA DALAM INTEGRATED CRIMINAL JUSTICE SYSTEM. Makara HubsAsia. 2013;8(3). 